\title{
Introducción a la Virología I
}

\author{
Introduction to Virology I
}

Cindy Peña M*, Nicolás Faúndes G

Laboratorio de Virología, Universidad de Valparaíso

*Autor para correspondencia: cindy.pena@uv.cl

RECIBIDO: 01 de Enero de 2019

APROBADO: 23 de Enero de 2019

DOI: 10.22370/bolmicol.2018.33.2.1387

LOS AUTORES DECLARAN NO TENER CONFLICTO DE INTERESES

Palabras claves: virus, patogenia, enfermedad.

Key words: virus, pathogeny, disease.

\section{RESUMEN}

Los virus han acompañado al hombre a través de toda su historia, provocando infecciones y plagas que han generado la muerte y el temor de poblaciones completas. Muchos han sido los investigadores que han contribuido a conocer la estructura, patogenia e inmunidad involucrada. Es fundamental conocer los aspectos básicos de los virus para entender la enfermedad y el tratamiento, por lo que esperamos contribuir a esto con los apuntes que a continuación presentamos.

\section{INTRODUCCIÓN}

La virología corresponde a una rama de la microbiología o de la patología que se centra en el estudio, clasificación y patogenia de los agentes virales, entre otros.

\section{RESEÑA HISTÓRICA}

La palabra Virus proviene del latín virus que significa toxina, veneno; luego se usó en patología como "sustancia venenosa que produce el organismo en determinadas enfermedades" (de ahí virulen-

\begin{abstract}
Viruses have accompanied humankind through their history, causing infections and producing death and fear in population. A lot of researchers have contributed to know the structure, pathogeny and immunity involved. To understand the disease and treatment is fundamental to know the basic aspects, which is the reason to present these notes.
\end{abstract}

to); para Pasteur, en 1860 era "germen patógeno"; la valoración actual surge en el siglo XX.

Hechos importantes que ocurrieron antes de que surgiera el concepto actual:

a. Descubrimiento de la vacuna contra la viruela (Jenner, 1796).

b. Vacunación contra la rabia (Pasteur, fines del siglo XX).

c. Ivanosky, biólogo ruso, fue el primer científico en aislar los virus en 1982 (virus del mosaico del tabaco). 
d. Beijerinck, en 1898 amplió este trabajo y le dio - Potencialmente patógenos el nombre de virus a estos agentes.

\section{CONCEPTO DE VIRUS}

Se distinguen por:

- Ser agentes sub-microscópicos
- Parásitos intracelulares obligados

- Poseer un solo tipo de ácido nucleico (ADN o ARN), nunca ambos

- Su unidad estructural básica es el virión

- No poseen organélos (ribosoma, mitocondrias, etc.)

\begin{tabular}{lcccccc}
\hline & $\begin{array}{c}\text { Cultivo en } \\
\text { medio } \\
\text { artificial }\end{array}$ & $\begin{array}{c}\text { División } \\
\text { por fisión } \\
\text { binaria }\end{array}$ & $\begin{array}{c}\text { Presencia } \\
\text { conjunta de } \\
\text { ADN y } \\
\text { ARN }\end{array}$ & Ribosomas & $\begin{array}{c}\text { Sensibilidad } \\
\text { a antibióticos }\end{array}$ & $\begin{array}{c}\text { Sensibilidad } \\
\text { a interferón }\end{array}$ \\
\hline Bacterias & $\mathrm{Si}$ & $\mathrm{Si}$ & $\mathrm{Si}$ & $\mathrm{Si}$ & $\mathrm{Si}$ & No \\
Micoplasmas & $\mathrm{Si}$ & $\mathrm{Si}$ & $\mathrm{Si}$ & $\mathrm{Si}$ & $\mathrm{Si}$ & No \\
Rickettsias & $\mathrm{No}$ & $\mathrm{Si}$ & $\mathrm{Si}$ & $\mathrm{Si}$ & $\mathrm{Sí}$ & No \\
Clamidias & $\mathrm{No}$ & $\mathrm{Si}$ & $\mathrm{Si}$ & $\mathrm{Si}$ & $\mathrm{Si}$ & $\mathrm{Si}$ \\
Virus & $\mathrm{No}$ & $\mathrm{No}$ & $\mathrm{No}$ & $\mathrm{No}$ & $\mathrm{No}$ & $\mathrm{Si}$ \\
\hline
\end{tabular}

Tabla 1. Comparación entre virus y otros microorganismos.

\section{ANALISIS DE LOS VIRUS}

Gracias a los adelantos en microscopía electrónica (M.E.) técnicas de difracción rayos X, ultracentrifugación, etc. ha sido posible analizar y purificar las partículas virales junto a los distintos constituyentes de ella.

\section{Tamaño:}

Los virus son submicroscópicos, es decir, están bajo el poder de resolución del microscopio de luz y por lo tanto, solo se pueden ver con Microscopia electronica. La excepción está constituida por los virus mayores como los del grupo de la viruela vacuna, los cuales miden unos $3000 \mathrm{~A}^{\circ}$ o $300 \mathrm{~nm}$. (1)

\section{Estructura viral:}

Los virus están constituidos por macromoléculas que se organizan del tal manera que le confieren sus propiedades biológicas y físico-químicas (1). Componentes Moleculares:

- Ácido Nucleico: ADN o ARN

- Proteínas
- Lípidos ( Virus envueltos)

- Hidratos de Carbono

Se organizan para formar Viriones.

En las figura 2 se observan virus desnudos y envueltos respectivamente e identifican con números las siguientes estructuras:

Protómeros: Es la agrupación de proteínas virales que forman unidades moleculares.

Capsómeros (3): Formado por protómeros, son las unidades morfo-moleculares que integran la nucleocápside.

\section{Cápside (1)}

Nucleocápside (4): Es el conjunto de ácido nucleico (2) y proteínas altamente organizado. Le confiere a las partículas virales diversas propiedades como estabilidad termodinámica y la capacidad de almacenar un máximo de masa en el menor volumen.

Envoltura (6)

Virión (5): Es la organización física de los virus como partículas. 
Introducción a la Virología I. - Peña C. et al.
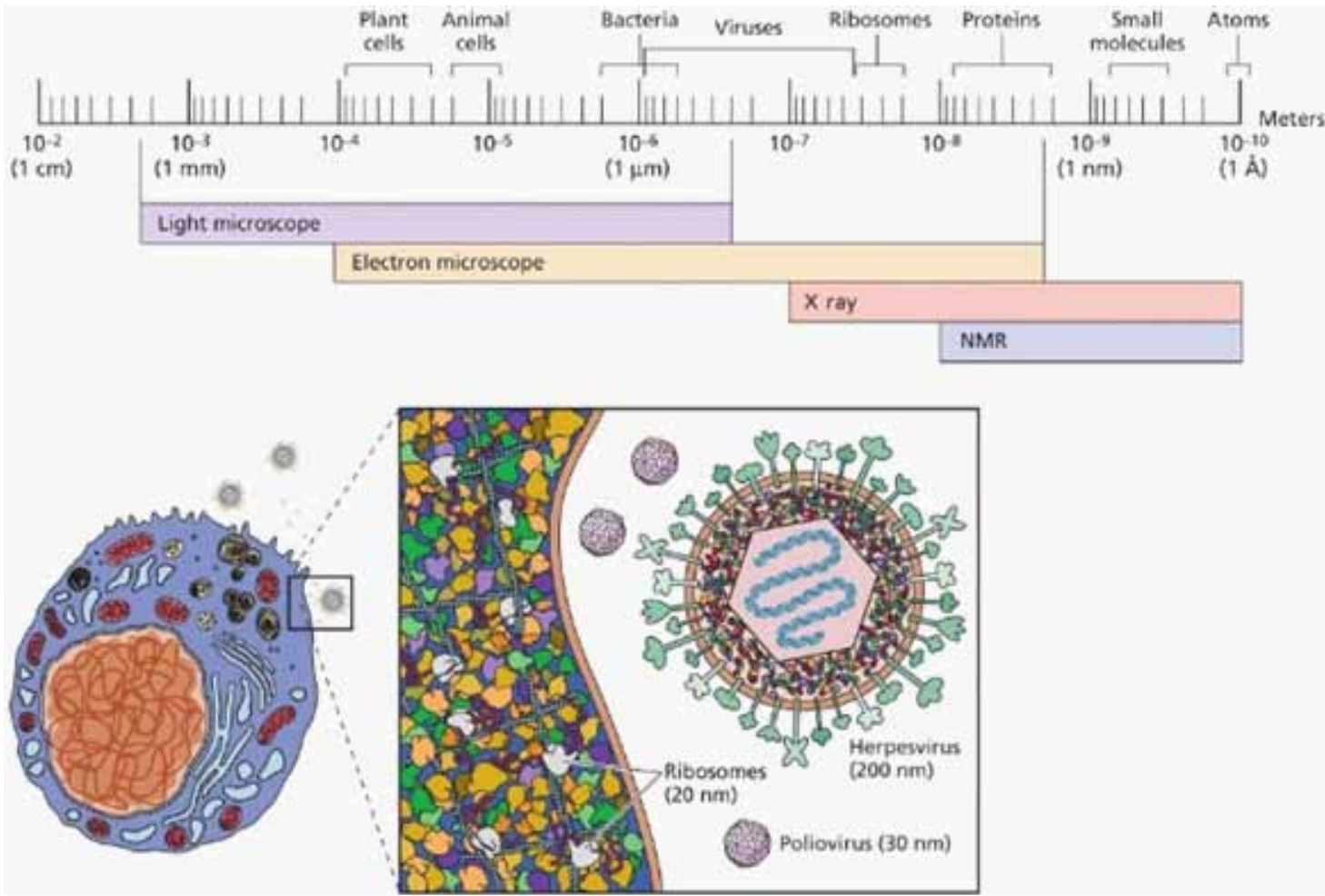

Figura 1. Tamaño de los virus en relación a otras moléculas biológicas (2).
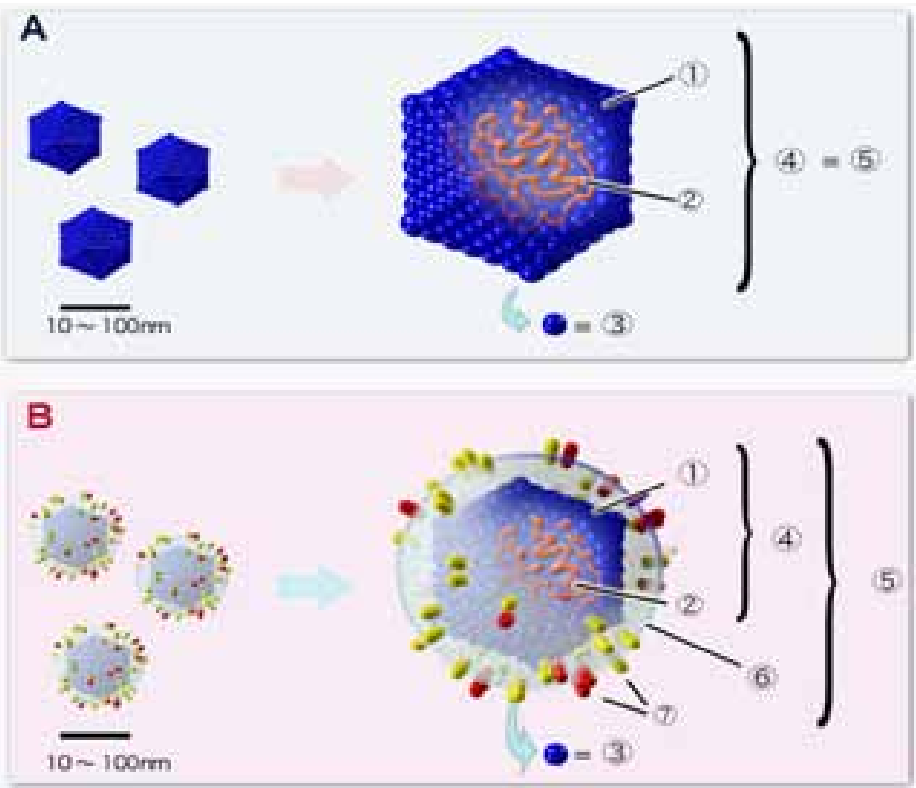

Figura 2. Virus desnudos y envueltos (3).

\section{Ordenamiento Nucleocápside:}

Esta estructura puede estar ordenada de acuerdo a cierta simetría, lo que les da una determinada morfología. Esta puede ser:
- Icosaedro: Poliedro regular de 20 caras planas triangulares.

- Helicoide: Estructura en espiral o hélice.

- Pleomorfa: Se observa en los virus con manto.

- Compleja: No hay una simetría regular. 
Estructura viral con Microscopía electrónica:

A) Complejo no envuelto (Bacteriófago T4)

B) Helicoidal desnudo (virus de mosaico del tabaco)

C) Envuelto forma de bala (rhabdovirus, estomatitis vesicular)

D) Icosaédrico desnudo

\section{Acidos nucleicos virales:}

- Los virus poseen un solo tipo de ácido nucleico; ADN o ARN, característico para cada virus.

- El ADN viral puede ser monoténico (ej.Parvovirus) o biténico (ej.herpes virus). El ARN viral puede ser monoténico (polio), biténico (rotavirus), o diploide o seudodiploide (retrovirus).
- La mayoría de los virus ADN patógenos para el hombre tienen un ADN biténico

- La mayoría de los virus ARN patógenos para el hombre son monoténicos.

El ácido nucleico constituye el genoma viral y su función es contener la información genética (genes), necesaria para la síntesis de las proteínas virales. Es así como el análisis y secuenciación de los ácidos nucleicos virales permite conocer la naturaleza de la proteína de un virus. Para algunos virus se conoce su secuencia nucleotídica completa y para otros sólo la naturaleza de ciertos genes. De esta forma se puede apreciar que los ácidos nucleicos virales poseen ciertas características en cuanto a su organización. Algunos poseen secuencias nucleótidicas repetidas e invertidas en determinadas regiones del ácido nucleico.

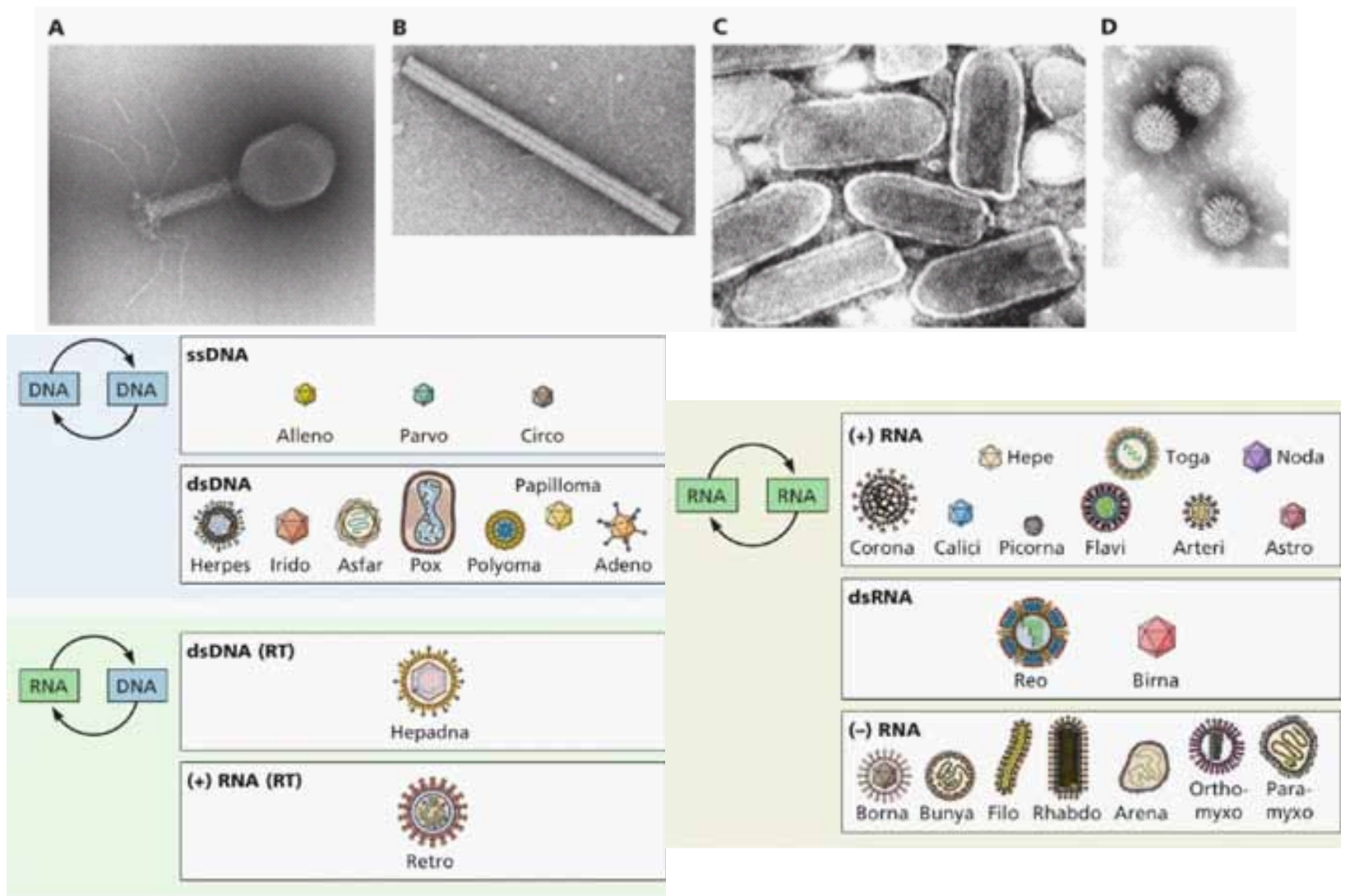

Figura 3. Estructuras virales con microscopía electrónica (2).

Figura 4. Familias de virus que infectan vertebrados, ordenadas de acuerdo a la naturaleza de sus genomas (4). 


\section{Proteinas virales:}

Las proteínas que forman parte de la estructura viral están codificadas en el genoma viral. No son muchas, porque los genomas virales son pequeños. Algunos virus (Ej. Polio) poseen 4 proteínas, y otros más complejos, cerca de $100(\mathrm{Ej}$. Poxvirus).

Las proteínas virales presentan ciertas propiedades y son responsables de diversas funciones biológicas. Algunas de ellas corresponden a la infectividad, protección del genoma viral, actividad enzimática, virulencia, inmunogenicidad, antigenicidad, etc.

Existe una relación entre la estructura proteica viral y su material genético. Esto quiere decir que variaciones de las proteínas virales, como consecuencia del cambio en el genoma, dan origen a variantes genéticas que determinan tipos y cepas que presentan distintas propiedades biológicas.

\section{Envoltura o manto:}

Algunos virus poseen una estructura externa, que rodea la nucleocápside, denominada manto

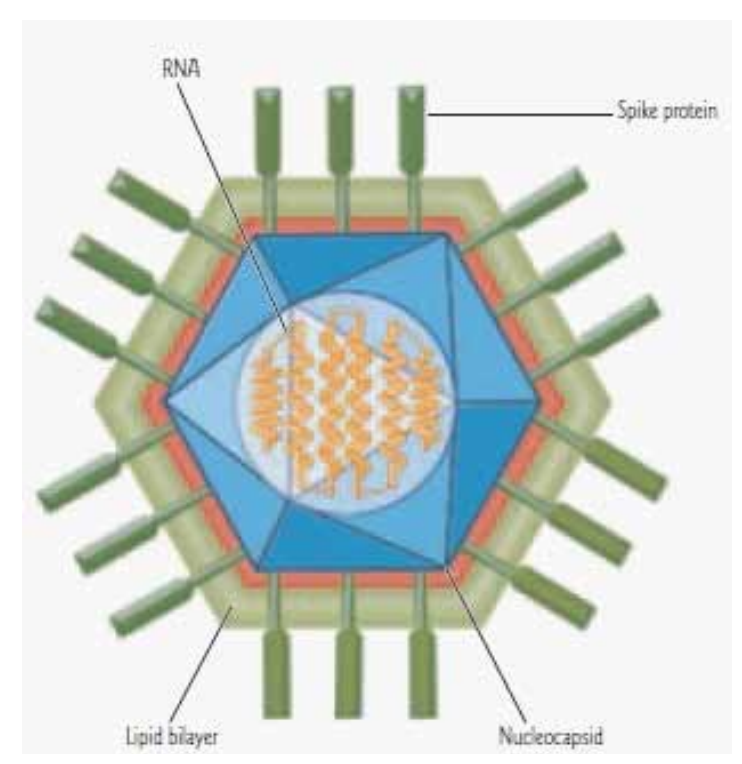

Figura 5. Virus Sinbis: icosaédrico envuelto (5). o envoltura. Este manto está constituido por lípidos e hidratos de carbono que se organizan como una bicapa lipídica con glupoproteínas insertas en ella. Esta bicapa es semejante a la membranas celulares, de hecho es tomada de la membrana plasmática o de la carioteca de las célula infectadas.

Como se puede apreciar no existen estructuras virales demasiado variadas, sino que de preferencia los virus presentan estas estructuras características que permiten su identificación y caracterización morfológica.

\section{Clasificación:}

Los virus pueden clasificarse de variadas maneras, tales como morfología, tipo de ácido nucleico, modo de replicación, huésped y tipo de enfermedad que causan. Actualmente existen 2 tipos de clasificaciones principales:

- Clasificación del ICTV (International Committee on Taxonomy of Viruses).

- Clasificación de Baltimore (5).

\section{Clasificación según estructura:}

1. Virus Desnudos $\rightarrow$ Solo nucleocápside (polio, rotavirus, etc.).

- Son liberados de la célula que infectan por lisis.

- Carecen de envoltura lipídica, siendo más estables a condiciones ambientales como temperatura, acidez, proteasas, detergentes, desecación.

- Pueden encontrarse con facilidad sobre fómites, manos, polvo, pequeñas gotitas, etc (resistentes a condiciones adversas).

- Son capaces de desecarse y conservar infectividad, pueden superar condiciones adversas del intestino, ser resistentes a los detergentes y aguas residuales insuficientemente tratadas. 
Introducción a la Virología I. - Peña C. et al.

- Curación depende de la inmunidad humoral.

2. Virus Envueltos $\rightarrow$ Nucleocápside con manto (influenza, herpes, etc.).

- Más lábiles a condiciones ambientales y son alterados por acidez, detergentes, desecación, calor, etc. por presencia de lípidos, proteínas y glucoproteínas en su membrana.

- Estos virus modifican la membrana celular durante la replicación y se liberan de la célula infectada por yemación a nivel de membrana celular no necesitando matar a la célula para diseminarse y en ocasiones por lisis celular.

- Necesitan humedad, no sobreviven en el tracto intestinal, se diseminan por gotitas grandes, secreciones o trasplante de órganos o sangre.

- Curación depende de la respuesta humoral y celular. Frecuentemente su capacidad patógena se debe a una respuesta inmunocelular.

\section{Clasificación taxonómica (ICTV):}

Este sistema basa la clasificación en órdenes, familias, subfamilias, géneros y especies. Por lo tanto, la estructura general de la taxonomía es la siguiente:

- Orden (-virales)

- Familia (-viridae)

- Subfamilia (-virinae)

- Género (-virus)

- Especie (-virus)
Ej.: Entre los virus ADN tenemos la familia Herpesviridae. Los miembros de esta familia son virus ADN de doble hélice de simetría cúbica con 162 capsómeros y con envoltura lipídica. Existen más de 100 especies conocidas de herpesviridae que infectan a un amplio espectro de animales. Ocho especies reconocidas infectan a los humanos, estas son:

1. Herpes simples:

a. Tipo 1

b. Tipo 2

2. Varicela Zoster

3. Epstein-Barr

4. Citomegalovirus

5. Herpes virus humano 6

6. Herpes virus humano 7

7. Herpes virus humano 8

\section{Clasificación de Baltimore:}

Esta clasificación distribuye los virus en 7 grupos fundamentales en función de la naturaleza del ácido nucleico viral y en el mecanismo de producción de ARNm.

Todos los virus deben generar cadenas positivas de ARN a partir de sus genomas para producir proteínas y replicarse a sí mismos, pero se utilizan distintos mecanismos en cada uno de los 7 grupos. 


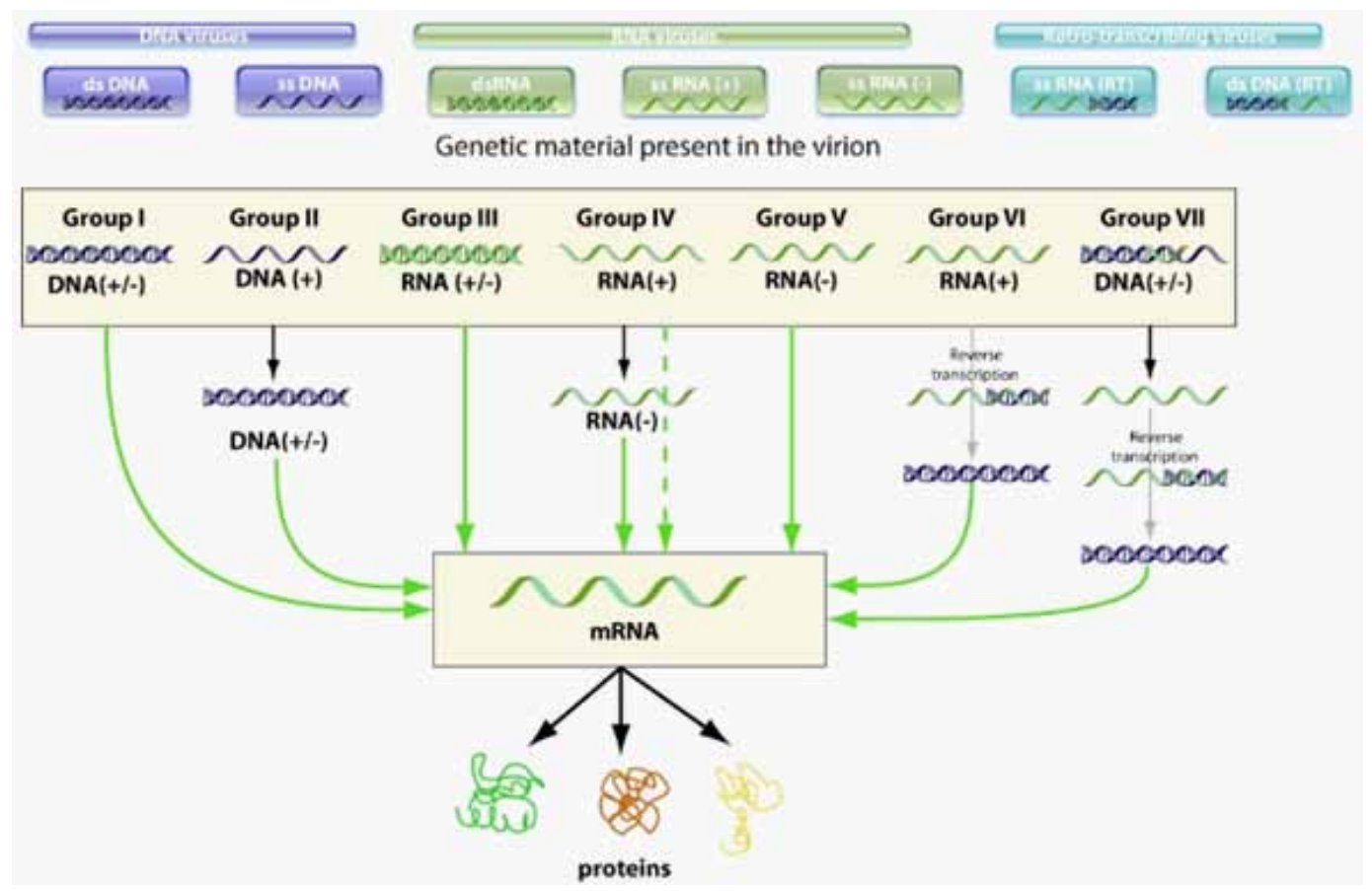

Figura 6. Clasificación viral de Baltimore, según genoma viral y mecanismo de obtención de ARN mensajero. (6)

\section{REFERENCIAS}

1. Virología clínica, $1^{\circ}$ edición, año 2011, Editorial Mediterraneo, Luis F. Avendaño, Marcela Ferrés, Vivian Luchsinger, Eugenio Spencer, capitulo 2 "Estructura y replicación de los virus"

2. Principles of virology, $4^{\circ}$ edicion, vol 2, Jane Flint, Lynn W. Enquist, Vincent R. Racaniello, Glenn F. Rall, Anna Marie Skalka capítulo 1, Pag. 13.

3. https://www.youbioit.com/es/article/shared-information/11116/que-son-las-celulas-parte-ii, sitio visitado en enero 2019.
4. Principles of virology, $4^{\circ}$ edicion, vol 2, Jane Flint, Lynn W. Enquist, Vincent R. Racaniello, Glenn F. Rall, Anna Marie Skalka, capitulo1, pág. 19.

5. Introduction to modern virology, sexta edicion, N.J. Dimmock, A.J. Easton, K.N.Leppard, Capítulo 3, estructura de las partículas virales, pág. 43.

6. http://viralzone.expasy.org/254, sitio visitado en enero 2019. 